\title{
Kunitz-Type Protease Inhibitor 1
}

National Cancer Institute

\section{Source}

National Cancer Institute. Kunitz-Type Protease Inhibitor 1. NCI Thesaurus. Code C107612.

Kunitz-type protease inhibitor 1 ( $529 \mathrm{aa}, \sim 58 \mathrm{kDa}$ ) is encoded by the human SPINT 1 gene. This protein plays a role in both growth factor signaling and the regulation of protease activity. 